\title{
PERNIKAHAN BEDA AGAMA DAN DAMPAK TERHADAP PENDIDIKAN AGAMA ANAK
}

\author{
Kaharuddin, M. Pd. I. dan Syafruddin, M. Pd.I \\ Institut Agama Islam (IAI) Muhammadiyah Bima \\ kaharazzam@gmail.com dan desilwan541@gmail.com
}

\section{Abstrak}

Allah Swt. sebagaimana dalam Al Quran surat al Nisa', surat al Dzariat maupun surat al Qiyamah telah memerintahkan kepada para hamba-hambaNya untuk mencari pasangan hidup atau menikah. Begitu pula Rasulullah Saw. dalam hadits-haditsnya. Jumhur ulama (mayoritas ulama) sepakat bahwa perintah tersebut bersifat wajib, karena banyaknya dalil-dalil nash yang menjelaskan, belum lagi beberapa pandangan dan pendapat ulama yang menjelaskan tentang akibat dan dampak negative yang terjadi apabila perintah tersebut tidak diindahkan. Selain menjaga pandangan dan hawa nafsu, khususnya bagi kaum laki-laki sebagaimana dalam hadits riwayat Muslim nomor 2486, tujuan lain yang tidak kalah penting dari sebuah pernikahan adalah melanjutkan kuturunan dengan melahirkan anak. Karena anak adalah bagian dari perhiasan dunia yang dengannya manusia menumpahkan rasa cinta dan sayangnya, hal ini disebutkan oleh Allah Swt dalam surat al Imran ayat 14. Namun demikian, anak bukan hanya sekedar perhiasan yang dengannya ditumpahkan rasa cinta dan sayang saja, lebih dari itu anak adalah titipan yang harus di jaga dan di didik sehingga kelak bisa bermanfaat bukan hanya untuk dirinya pribadi tapi juga untuk masyarakat, bangsa, agama dan termasuk kedua orang 
tuanya. Oleh sebab itu dalam hadits-haditsnya seringkali Rasul Saw. mengingatkan untuk berhati-hati dalam memilih pasangan hidup, apa dan bagaimana serta seperti apa anak keturunan nanti akan sangat berpengaruh terhadap siapa orang tuanya. Allah Swt.-pun dengan tegasnya mengatakan dalam surat al Baqarah ayat 221 bahwa "Budak yang hitam legam tapi muslim lebih baik dari orang musyrik yang putih, cantik serta kaya." Dewasa ini terjadi beberapa kali, penikahan beda agama; kadang calon suami Islam sedangkan calon istri musyrik atau sebaliknya. Dengan memilih yang beragama Islam saja belum mampu menjamin bahwa anak akan menjadi pribadi yang baik, apalah lagi dengan memilih orang musyrik lagi kafir. Maka penulis melaui tulisan singkat ini, hendak menjelaskan hukum nikah beda agama serta dampak serius yang ditimbulkan akibat nikah beda agama, dengan harapan memberikan manfaat dan tambahan ilmu bagi diri pribadi dan para pembaca serta menjadi bahan rujukan dan pertimbangan bagi pasangan yang hendak mencoba larangan Allah Swt. ini.

Keyword: Pernikahan, Beda Agama, Dampak Negative, Pendidikan Anak.

\section{A. Pendahuluan}

Satu-satunya Nabi Allah yang mendapat julukan sebagai Abu al Anbiya' (bapaknya para Nabi) adalah Nabi Ibrahim As. Bagaimana tidak, beliau dengan segala kelebihan yang Allah berikan kepadanya, mendapatkan dua orang istri (pasangan hidup) yang sama-sama memilki tingkat shalihah yang tinggi lagi ta'at, bukan hanya kepada Allah sebagai Tuhan-Nya tapi juga kepada Nabi Ibrahim sebagai seorang suami. Selain itu, Nabi Ibrahim juga memilki dua orang anak, yaitu Ismail As.

Sangaji Jurnal Pemikiran Syariah dan Hukum 
dan Ishaq As. dan dua-duanya adalah Nabi Allah. Lalu dari garis keturunan Ismail As lahirlah Nabiyullah Muhammad Saw., sedangkan dari garis keturunan Ishaq As., lahir Nabi Ya'kub, Nabi yusuf, Nabi Ayyub sampai dengan Nabi Isa As.

Lalu apa sebenarnya rahasia yang dimiliki atau dilakukan oleh Nabi Ibrahim As., sehingga mampu melahirkan keturunan-keturunan yang luar biasa? Kurang lebih 80 tahun lamanya Nabi Ibrahim berdoa dan memohon kepada Allah agar kiranya beliau diberikan keturunan yang shalih lagi ta'at. Doa tersebut terukir indah dalam Al Quran surat al Shaffat ayat 100:

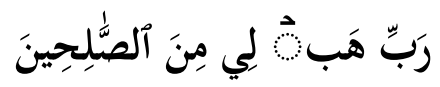

Terjemahnya:

"Ya Tuhanku, anugrahkanlah kepadaku (seorang anak) yang termasuk orang-orang yang saleh." (QS. Al Shaffat: 100)

Ketika Ismail As. beranjak dewasa, kembali Allah menguji keshalihan dan ketaatan dua orang Nabi tersebut. Allah memerintahkan kepada Ibrahim As untuk menyembil anaknya Ismail As dengan wahyu melalui mimpi. Allah berfirman:

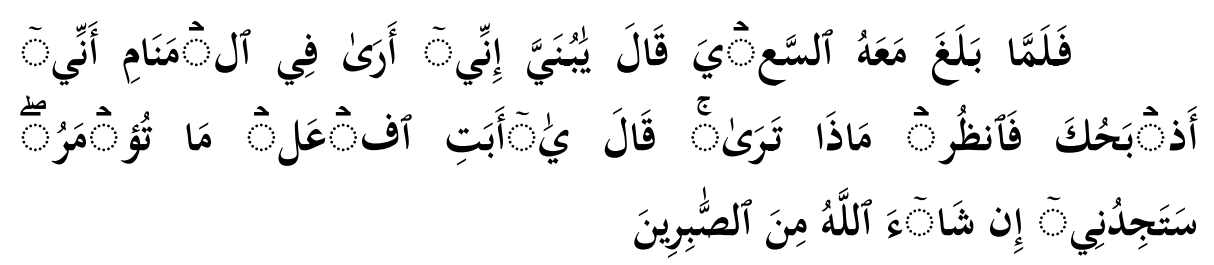

Terjemahnya:

"Maka tatkala anak itu sampai (pada umur sanggup) berusaha bersama-sama Ibrahim, Ibrahim berkata: "Hai anakku sesungguhnya aku melihat dalam mimpi bahwa aku menyembelihmu. Maka fikirkanlah apa pendapatmu!" Ia menjawab: "Hai bapakku, kerjakanlah apa yang diperintahkan kepadamu; insya Allah kamu akan mendapatiku termasuk orang-orang yang sabar"." (QS. Al Shaffat: 102) 
Kisah tentang Nabi Ibrahim dengan keluarga; anak dan istrinya adalah sebuah gambaran singkat tentang pentingnya memilih pasangan hidup yang dari pasangan yang baik akan melahirkan keturnan berubapa anak-anak yang baik. Karena dari orang tua yang shalih dan shalihah dengan didikan yang baik akan melahirkan keturunan yang baik pula, sebaliknya dari orang tua yang buruk (musyrik) dengan didikan yang buruk akan melahirkan anak katurunan yang buruk (musyrik) pula. karena tiada keburukan yang lebih buruk dari musyrik atau menyekutukan Allah Swt. sebagai Tuhan semesta alam.

\section{B. Pengertian Nikah}

Sebelum terlalu jauh membahas tentang nikah beda agama serta dampak yang timbul khususnya bagi anak keturunan terlebih dalam hal pendidikan agamanya, maka sedikit akan dijelaskan terlebih dahulu tentang pengertian nikah itu sendiri.

Nikah berasal dari bahasa arab (نَكَح يَنْكُح نِكَاحًا) yang artinya secara bahasa adalah al jam'u dan al dhammu yang atau kumpul atau mengumpulkan. Sedangkan secara istilah menurut ilmu fiqih dari para fuqaha mendefinisikan nikah adalah suatu akad perjanjian yang mengandung kebolehan melakukan hubungan seksual (persetubuhan) dengan memakai kata-kata (lafaz) nikah atau tazwij. ${ }^{1}$ Menurut Undang-undang No. 1 Tahun 1974 tentang Perkawinan, pernikahan didefinisikan sebagai ikatan lahir batin antara seorang pria dengan seorang wanita sebagai suami istri dengan tujuan membentuk keluarga (rumah tangga) yang bahagia dan kekal berdasarkan Ketuhanan Yang Maha Esa. Sedangkan di dalam Kompilasi Hukum Islam pernikahan adalah akad yang sangat kuat atau mitsaqan ghalizhah untuk

1 Rahmat Hakim. 2000. Hukum Perkawinan Islam. Bandung: CV. Pustaka Setia. Hlm. 11-12. Lihat juga: Zakiah Daradjat. 1995. Ilmu Figh. Yogyakarta: Dana Bhakti Wakaf. Hlm. 37.

Sangaji Jurnal Pemikiran Syariah dan Hukum 
menaati perintah Allah dan melaksanakannya merupakan ibadah. $^{2}$

Sedangkan nikah menurut syaikh Wahbah al Zuhaili dalam kitabnya "Fiqhu al Islami wa Adillatuhu" adalah akad yang menghalalkan seorang pria untuk memiliki atau berhubungan dengan wanita; baik berhubungan badan, sekedar mencium, bercanda gurau dan sebagainya selama wanita tersebut bukan sebagai mahramnya secara nasab, persusuan atau kerabat dekat yang haram untuk dinikahi. ${ }^{3}$

\section{Dasar Hukum Nikah}

Disebutkan sebelumnya bahwa nikah adalah merupakan perintah Allah Swt. dan Rasul-Nya yang mayoritas ulama sepakat bahwa hukum melaksanakannya adalah wajib. Adapun dalil dari ketetapan hukum tersebut adalah sebagai berikut:

\section{Dari Al Quran}

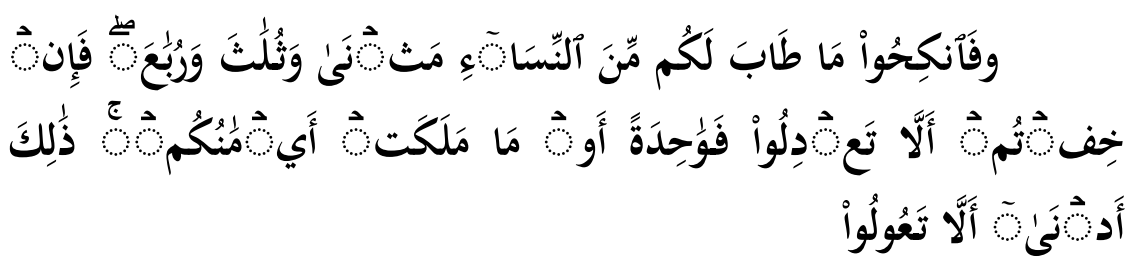

Terjemahnya:

"Maka kawinilah wanita-wanita (lain) yang kamu senangi: dua, tiga atau empat. Kemudian jika kamu takut tidak akan dapat berlaku adil, maka (kawinilah) seorang saja, atau budak-budak yang kamu miliki. Yang demikian itu adalah lebih dekat kepada tidak berbuat aniaya." (QS. Al Nisa': 3) Sepakat ulama, bahwa perintah menikah dalam ayat ini bersifat

2 Lihat: Undang-Undang Republik Indonesia Nomor 1 Tahun 1974 Tentang Perkawinan.

${ }^{3}$ Wahbah al Zuhaili. 1985. Fighu al Islami wa Adillatuhu Juz. VII. Cetakan II. Damaskus: Dar al Fikri. Hlm. 29. 
wajib, bahkan dianjurkan untuk menikah lebih dari satu dengan ketentuan berbuat adil terhadap para istri.

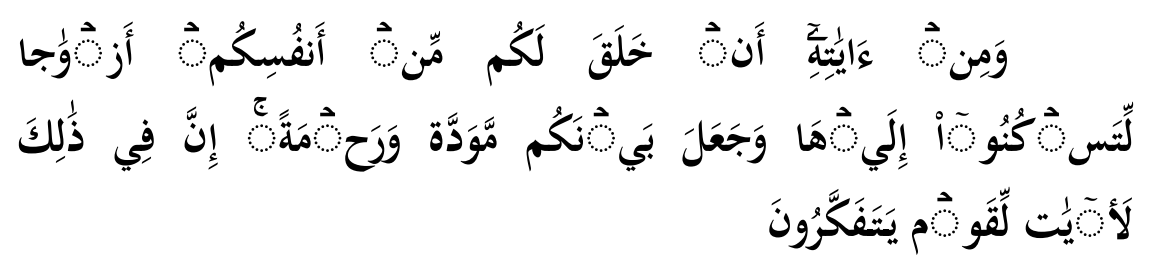

Terjemahnya:

"Dan di antara tanda-tanda kekuasaan-Nya ialah Dia menciptakan untukmu isteri-isteri dari jenismu sendiri, supaya kamu cenderung dan merasa tenteram kepadanya, dan dijadikanNya diantaramu rasa kasih dan sayang. Sesungguhnya pada yang demikian itu benar-benar terdapat tanda-tanda bagi kaum yang berfikir." (QS. Al Rum: 21) Dalam ayat ini Allah menjelaskan fungsi atau manfaat yang diperoleh dari seorang pasangan, yaitu saling memberikan ketentraman dan saling berkasih sayang. Yang mafhum mukhalafah-nya (arti sebaliknya) bahwa sulit untuk seseorang untuk mendapatkan ketentraman dan kasih sayang kecuali dari pasangan.

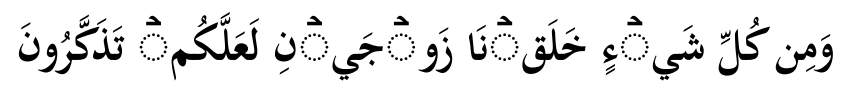

Terjemahnya:

"Dan segala sesuatu Kami ciptakan berpasang-pasangan supaya kamu mengingat kebesaran Allah." (QS. Al Dzariat: 49) Dalam ayat ini pula Allah menjelaskan bahwa bukan hanya manusia yang diciptakan dalam keadaan berpasangpasangan, seluruh makhluk-Nya Allah memang dari awal menciptakannya secara berpasang-pasangan yang dengannya manusia mampu dan bisa mengingat dan mengetahui kebesaran Allah. Hal ini sebagaimana Allah tegaskan dalam firman-Nya:

Sangaji Jurnal Pemikiran Syariah dan Hukum 


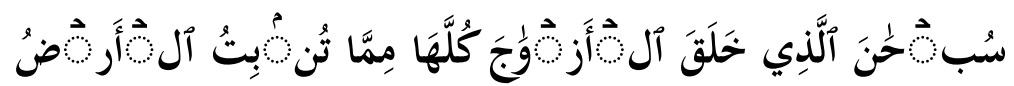

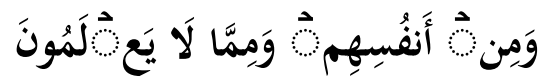

Terjemahnya:

"Maha Suci Tuhan yang telah menciptakan pasangan-pasangan semuanya, baik dari apa yang ditumbuhkan oleh bumi dan dari diri mereka maupun dari apa yang tidak mereka ketahui." (QS. Yasin: 36)

\section{Dari Sunnah (hadits)}

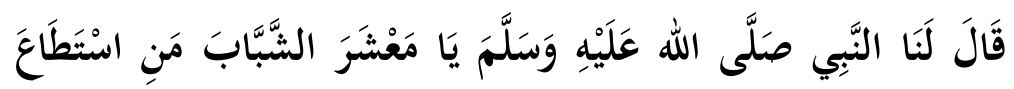

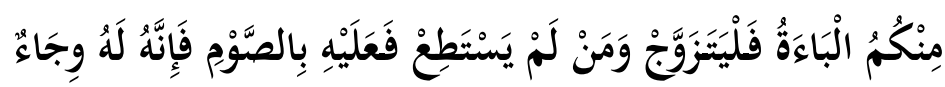

Artinya:

Nabi Saw. telah bersabda kepada kita: "Wahai sekalian pemuda, siapa di antara kalian yang telah mempunyai kemampuan, maka hendaklah ia menikah, dan barangsiapa yang belum mampu, hendaklah ia berpuasa karena hal itu akan lebih bisa meredakan gejolaknya." (HR. Al Bukhari, Muslim, Al Tirmidzi, Al Nasa'i, Ibnu Majah, Al Darimi dan Ahmad)

عَنْ أَنَسْ: أَنَّ نَفَرًا مِنْ أَصْحَابِ النَبِي صَلَّى الله عَلَيْهِ وَسَلَّمَ سَأَلُوا

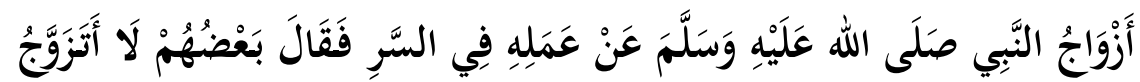

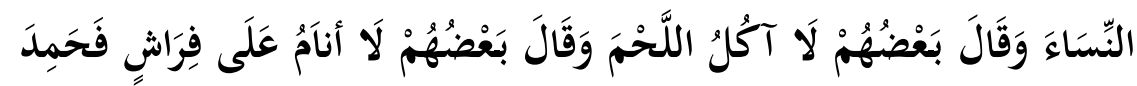

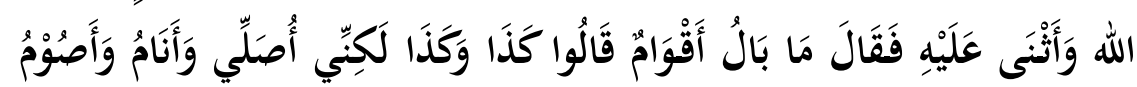

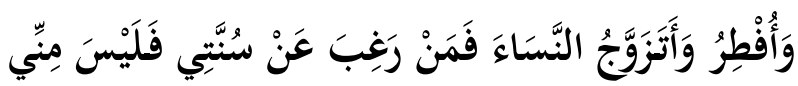

Artinya:

Dari Anas bahwa sekelompok orang dari kalangan sahabat Nabi Saw. bertanya kepada isteri-isteri Nabi mengenai amalan beliau yang tersembunyi. Maka sebagian 
dari mereka pun berkata: "Saya tidak akan menikah." Kemudian sebagian lagi berkata: "Saya tidak akan makan daging.' Dan sebagian lain lagi berkata: "Saya tidak akan tidur di atas kasurku." Mendengar ucapan-ucapan itu, Nabi Saw. memuji Allah dan menyanjung-Nya, kemudian beliau bersabda: "Ada apa dengan mereka? mereka berkata begini dan begitu, padahal aku sendiri shalat dan juga tidur, berpuasa dan juga berbuka, dan aku juga menikahi wanita. Maka siapa yang saja yang membenci sunnahku, berarti bukan dari golonganku." (HR. Al Bukhari, Muslim, Nasa'i, Al Darimi, Ahmad, dan Ibnu Hibban)

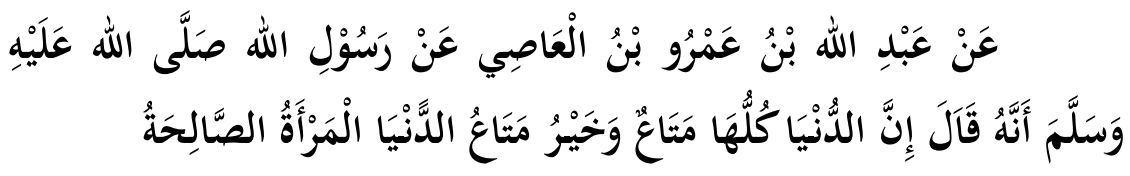

Artinya:

Dari Abdullah bin 'Amru bahwasannya Rasulullah Saw. bersabda: "Dunia adalah perhiasan dan sebaik-baik perhiasan adalah wanita shalihah." (HR. Muslim, Nasa'i dan Ahmad) Dan masih banyak lahi dalil dari nash yang menjelaskan dan menerangkan tentang wajibnya perintah menikah.

\section{Hukum Nikah}

Secara bahasa dengan melihat hadits dengan konteksnya, maka hukum nikah adalah sunnah. Namun jika melihat secara istitilah dangan penjelasan dari para ulama fikih, maka hukum nikah adalah wajib. Wajib maksudnya disini adalah secara umum dalam keadaan normal.

Namun dengan melihat beberapa keadaan khususnya dari seorang laki-laki, maka nikah menurut para fuqaha (ulama ahli fikih) terbagi hukumnya dalam beberapa bagian: ${ }^{4}$

${ }^{4}$ Wahbah al Zuhaili. 1985. Fighu al Islami wa Adillatuhu Juz. VII. Cetakan II. Damaskus: Dar al Fikri. Hlm. 31-33.

Sangaji Jurnal Pemikiran Syariah dan Hukum 


\section{Wajib}

Menurut para ulama fikih nikah menjadi wajib ketika dikhawatirkan akan terjerumus dalam perbuatan zina apabila tidak segera menikah, sedangkan ia mampu untuk menyediakan mahar dan memberi nafkah lahir dan batin kepada pasangannya (istri), mengetahui hukum syariat, dan tidak mampu lagi menahan hawa nafsunya walaupun dengan berpuasa atau yang lainnya. Karena sesuatu yang menyempurnakan kewajiban maka hukumnya wajib.

\section{Haram}

Nikah menjadi sesuatu yang diharamkan apabila seseorang merasa yakin bahwa apabila menikah, malah akan mendzalimi pasangannya (istri) atau membahayakannya. Karena mungkin lemah; baik dari segi syahwat atau memberi nafkan bagi pasangannya, atau tidak mampu berbuat adil apabila menikah lagi dengan wanita lain (pologami). Karena sesuatu yang berpotensi mendatangkan keharaman maka hukumnya haram.

\section{Makruh}

Nikah berubah hukumnya menjadi makruh (lawan dari sunnah) apabila seseorang tidak yakin mampu memberi nafkah kepada pasangannya (istri) yang berujung pada membahayakan atau menyeretnya dalam keburukan, termasuk diantaranya adalah tidak mampu atau tidak yakin mampu dalam membina keluarga terlebih istrinya.

\section{Sunnah atau dianjurkan}

Nikah menjadi sebuah sunnah atau sesuatu yang dianjurkan apabila seseorang tersebut dikategorikan mampu berbuat adil, namun apabila tidak menikah maka tidak juga ditakutkan terjerumus dalam perbuatan zina serta kalau menikah tidak ditakutkan akan menzhalimi pasangannya (istri). Namun menurut Imam Syafi'i, keadaan 
seperti ini adalah keadaan yang hukum nikah menajdi mubah bukan dianjurkan (sunnah).

\section{E. Nikah Beda Agama}

Perkembangan pemikiran dan kebutuhan manusia, kadang menghadirkan sesuatu yang positif namun tidak jarang menimbulkan hal negative. Pada masa-masa orde lama, sekitar tahun 1960 sampai 2000 pernikahan masih dianggap sesuatu yang sangat sakral sehingga jarang terjadi perceraian. Orang tua dalam memilih menantu sangat selektif, penilaian dalam hal agama adalah sesuatu yang pertama ditanyakan dan dilihat. Karena dengan agama, seseorang mampu membimbing dan mendidik istri terlebih anak-anaknya sehingga menjadi anak yang shalih lagi baik.

Dewasa ini, hal tersebut di atas sudah tidak perhatikan lagi. Mapan dalam hal duniawi adalah penilaian utama oleh para calon mertua dalam menentukan pasangan anak-anaknya. Agama adalah sesuatu yang dianggap privasi dan tidak boleh ada campur tangan orang tua, sehingga anak bebas memilih dengan siapa yang diinginkannya. Maka tidak heran, anakanakpun berkembang sesuai dengan keinginan masing-masing tampa pendidikan agama dari orang tua.

Namun disisi lain, karena negara Indonesia adalah negara dengan penduduk mayoritas Islam maka hukum yang yang ada di Indonesia selain menggunakan hukum-hukum perintah (negara) juga masih memiliki Majelis Ulama Indonesia (MUI) yang selalu hadir memberikan fatwa terkait hukumhukum agama Islam yang salah satunya nikah beda agama.

Dan ternyata larangan terhadap nikah beda agama ini tidak hanya terjadi pada agama Islam saja, dalam agama lain- 
pun ditemukan larangan untuk meikah dengan seseorang yang berbeda kayakinan. Diantaranya: ${ }^{5}$

\section{Menurut hukum Kristen}

Agama Kristen di Indonesia terbagi menjadi dua aliran yaitu:

a) Katolik

Dalam hukum Katolik suatu perkawinan dianggap kudus, ikatan erat dan tidak terceraikan. Menurut Koningsmann dalam kitab Kanonik ${ }^{6}$ menyatakan bahwa terdapat terdapat 12 larangan dan halangan dalam perkawinan yang terangkum dalam 4 pokok yaitu: ${ }^{7}$

1) Tiga perjanjian yang berasal dari perjanjian perkawinan.

2) Rintangan karena agama.

3) Tiga halangan karena dosa berat.

4) Tiga hubungan karena persaudaraan.

Dari sini dapat diambil kesimpulan bahwa Kristen Katolik mengharamkan Perkawinan Beda Agama.

5 Ratna Jati Ningsih. 2012. Perkawinan Beda Agama (Studi Analisis Pemikiran Quraish Shihab dalam Tafsir Al-Misbah). Tidak Diterbitkan. Fakultas Syari'ah dan Ekonomi Islam Institut Agama Islam Negeri (IAIN) Surakarta. Hlm. 69-71. Lihat juga: Jane Marlen Makalew. 2013. Akibat Hukum Dari Perkawinan Beda Agama Di Indonesia. Lex Privatum, Volume I, Nomor 2 April Juni 2013. Hlm. 133-137.

6 Kitab Kanonik yaitu kitab resmi yang dijadikan rujukan oleh orang Katolik yang menyangkut hukum-hukum kehidupan sehari-hari. Kitab ini hasil ijtihad dari kitab indunya yaitu Injil, karena untuk merujuk pada Injil langsung terlalu sulit dipahami bagi orang awam karena bahasanya yang teramat filosofis dan dalam. Kitab ini disusun oleh para ulama Katolik. Atau dalam kontek Islam kitab ini sejajar dengan kitab fikih resmi dari suatu madzhab.

7 Lihat: Thtiyanto. 2003. Perkawinan Campuran dalam Negara RI. Jakarta: Badan Litbang Agama dan Diklat Keagamaan RI Depag. Hal. 128. 
b) Protestan

Agama Kristen mendefinisikan bahwa perkawinan adalah persekutuan hidup yang meliputi keseluruhan hidup yang menghendaki laki-laki dan perempuan menjadi satu. Satu dalam kasih Tuhan satu dalam mengasihi, satu dalam kepatuhan satu dalam menghayati kemanusiaan dan satu dalam memikul beban pernikahan. ${ }^{8}$

Persekutuan Gereja Indonesia (PGI) dan Gereja Kristen Indonesia (GKI) telah mensepakati bahwa orang Kristen boleh menikah dengan orang non Kristen tapi dengan syarat mereka harus menikah di gereja dan anak-anaknya nanti harus dididik menurut ajaran agama Kristen. ${ }^{9}$ Gagasan di atas pada asasnya hukum agama Kristen juga tidak menghendaki umatnya untuk menikah dengan agama non Kristen.

\section{Menurut Hukum Hindu}

Menurut Pudja dalam hukum Hindu memberikan pengaturan secara khusus mengenai upacara perkawinanyaitu dengan upacara suci pernikahan Pedande. Sedangkan Pedande hanya mau melaksanakan pernikahan apabila para calon pengantian sama-sama beragama Hindu. ${ }^{10}$

Di sini memberikan kesimpulan bahwa Pedande tidak mungkin memberkati atau menyelenggarakan upacara perkawinan antara mereka yang masih berbeda agama atau dalam istilah lainnya di dalam hukum Hindu tidak

${ }^{8}$ Lihat: Abineno. 1982. Manusia; Suami dan Istri. Jakarta: BPK Gunung Mulia. Hal. 19.

${ }^{9}$ Lihat: Ihtiyanto. 2003. Perkawinan Campuran dalam Negara RI. Jakarta: Badan Litbang Agama dan Diklat Keagamaan RI Depag. Hal. 133.

10 Lihat: Ihtiyanto. 2003. Perkawinan Campuran dalam Negara RI. Jakarta: Badan Litbang Agama dan Diklat Keagamaan RI Depag. Hal. 134.

Sangaji Jurnal Pemikiran Syariah dan Hukum 
membuka peluang sama sekali memberikan kesempatan kepada umatnya untuk menikah dengan orang yang beragama di luar Hindu.

\section{Menurut Hukum Budha}

Menurut ajaran Budha, agama Budha tidak menuntut kesempurnaan pada diri manusia. Agama Budha hanya melihat ajaran moral dan amalan. Dalam tradisi Budha mengenai pemberlakuan hukum lebih menekankan untuk menuruti ajaran hukum negara yang berlaku (Sruti) dan hukum tradisi (Smriti) setempat. ${ }^{11}$

Perkawinan Beda Agama adalah tindakan hukum yang tidak konstitusional menurut hukum Negara dan juga tidak selaras dengan ajaran moral atau tradisi masyarakat Indonesia secara kolektif. Karena hal itu masih dipandang tabu oleh sebagian besar masyarakat Indonesia (nulayani adat) sehingga disini agama Budha juga tidak memberikan peluang bagi umatnya untuk menikah dengan umat agama lain.

Nikah beda agama di Indonesia saat ini, selain sudah menjadi sesuatu yang sedikit biasa juga menjadi tren terkini untuk mendapatkan rating dan meningkatkan popularitas, khususnya para artis. Sesuatu yang mungkin tidak disadari adalah bahwa sebagai public figure pastinya akan menjadi contoh bagi para follower yang fanatik (fans). Yang kalau tidak segera dicegah secara serius dengan tindakan, maka tidak heran pada masa akan datang pernikahan beda agama akan menjadi sesuatu lumrah dan benar-benar dianggap biasa yang terjadi di tengah kehidupan masyarakat awam.

11 Lihat: Munir Fuady. 2009. Sejarah Hukum. Cetakan I. Bogor: Ghalia Indonesia. Hal. 57. 
Yang dimaksud pernikahan beda agama dalam pembahasan ini adalah salah satu dari pasangan beragama Islam (baik calon suami atau istri) dan yang lain beragama non Islam (Kristen atau Hindu misalnya). Dalam Islam pernikahan seperti ini adalah sesuatu yang benar-benar dilarang dan diharamkan oleh Allah dan Rasul-Nya, bahkan dengan dengan tegas Allah menjelaskan bahwa seorang budak wanita yang muslim lebih baik dari seorang musyrik walaupun memilki sesuatu yang lebih istimewa serta menarik hatimu dan begitu sebaliknya, Allah berfirman:

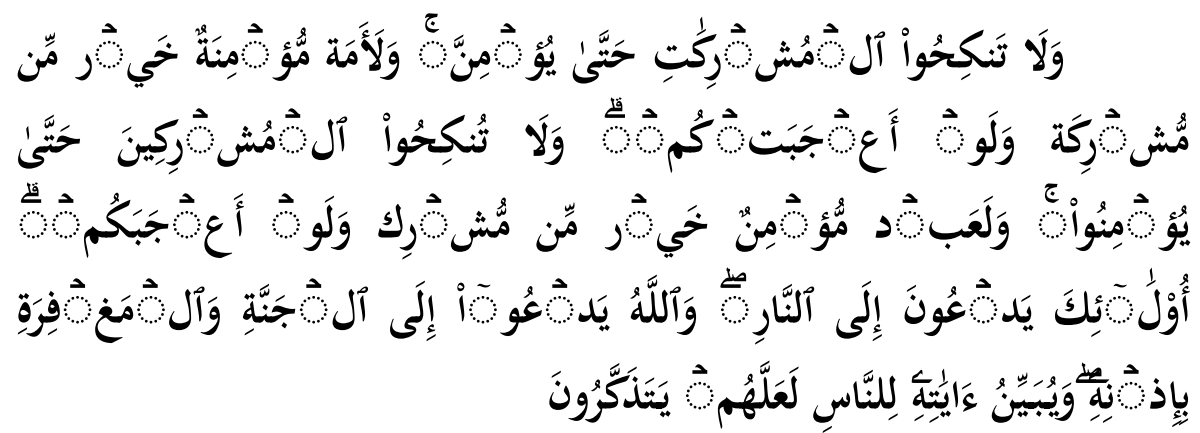

Terjemahnya:

"Dan janganlah kamu menikahi wanita-wanita musyrik, sebelum mereka beriman. Sesungguhnya wanita budak yang mukmin lebih baik dari wanita musyrik, walaupun dia menarik hatimu. Dan janganlah kamu menikahkan orang-orang musyrik (dengan wanitawanita mukmin) sebelum mereka beriman. Sesungguhnya budak yang mukmin lebih baik dari orang musyrik, walaupun dia menarik hatimu. Mereka mengajak ke neraka, sedang Allah mengajak ke surga dan ampunan dengan izin-Nya. Dan Allah menerangkan ayat-ayatNya (perintah-perintah-Nya) kepada manusia supaya mereka mengambil pelajaran." (QS. Al baqarah: 221)

Memaknai ayat ini, jumhur ulama (mayoritas ulama) sepakat bahwa pernikahan beda agama adalah haram hukumnya dengan alasan apapun. Demikian hal-nya yang difatwakan oleh Majelis Ulama Indonesia (MUI) tentang 
perkawinan beda agama bahwa (1) Perkawinan beda agama adalah haram dan tidak sah. (2) Perkawinan laki-laki muslim dengan wanita Ahlu Kitab, menurut qaul mu'tamad, adalah haram dan tidak sah. ${ }^{12}$ Tidak sampai dipernikahan beda agama saja, dalam fatwanya Majelis Ulama Indonesia (MUI) juga mengatakan pada point kedua bahwa Perkawinan laki-laki muslim dengan wanita Ahlu Kitab, menurut qaul mu'tamad, adalah haram dan tidak sah.

Pada hakikatnya peraturan pemerintah Repubrik Indonesia-pun telah menyatakan bahwa pernikahan beda agama dianggap tidak sah dan batal jika aturan agama melarang serta peraturan lain yang berlaku. ${ }^{13}$ Numun oleh beberapa praktisi hukum menyatakan bahwa masih ada celah yang bisa dilalui sehingga peraturan dan fatwa yang berlaku bisa di lawan. Seperti mengatas namakan Hak Asasi manusia sebagaimana dalam UU Hak Asasi Manusia No 39 tahun 1999 yang menyebutkan bahwa setidaknya terdapat 60 hak sipil warga negara yang tidak boleh diintervensi atau dikurangi oleh siapapun. ${ }^{14}$

Selain ayat yang disebutkan di atas, terdapat dalil-dalil lain yang mejelaskan tentang haramnya menikah beda agama, diantaranya:

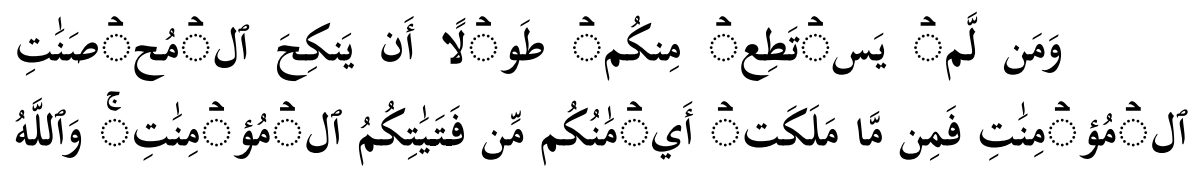

12 Lihat: Fatwa Majelis Ulama Indonesia Nomor: 4/Munas Vii/Mui/

/2005 Tentang Perkawinan Beda Agama. Hlm. 447.

13 Lihat: Undang-Undang Republik Indonesia Nomor 1 Tahun 1974 Tentang Perkawinan Pasal 8 Point F.

14 Redaksi Ruangmom. 2020. Apakah Mungkin Menikah Beda Agama di Indonesia?. diakses 26 February 2020. https://www.ruangmom.com/menikahbeda-agama.html 


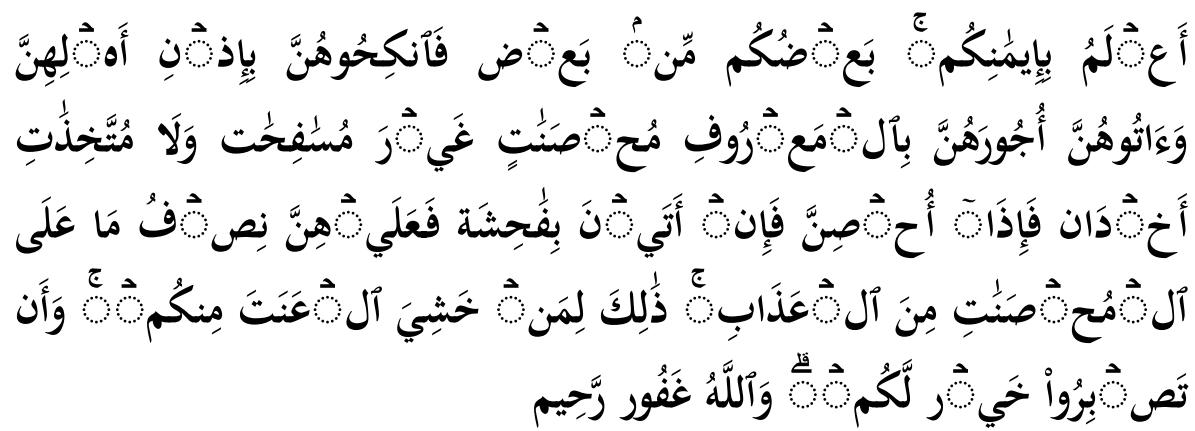

Terjemahnya:

"Dan barangsiapa diantara kamu (orang merdeka) yang tidak cukup perbelanjaannya untuk mengawini wanita merdeka lagi beriman, ia boleh mengawini wanita yang beriman, dari budak-budak yang kamu miliki. Allah mengetahui keimananmu; sebahagian kamu adalah dari sebahagian yang lain, karena itu kawinilah mereka dengan seizin tuan mereka, dan berilah maskawin mereka menurut yang patut, sedang merekapun wanita-wanita yang memelihara diri, bukan pezina dan bukan (pula) wanita yang mengambil laki-laki lain sebagai piaraannya; dan apabila mereka telah menjaga diri dengan kawin, kemudian mereka melakukan perbuatan yang keji (zina), maka atas mereka setengah hukuman dari hukuman wanita-wanita merdeka yang bersuami. (Kebolehan mengawini budak) itu, adalah bagi orangorang yang takut kepada kemasyakatan menjaga diri (dari perbuatan zina) di antara kamu, dan kesabaran itu lebih baik bagimu. Dan Allah Maha Pengampun lagi Maha Penyayang." (QS. Al Nisa': 25)

Dalam ayat ini, Allah menjelaskan bahwa ketika seseorang yang tidak mempu membiayai atau memberikan mahar yang cukup terhadap wanita merdeka, maka boleh menikahi budak-budak perempuan muslim dengan mahar yang patut atau semampunya. Dengan tidak menyebut apalagi sampai membolehkan untuk menikahi wanita ataupun budak musyrik.

Demikian pula dalam hadits Rasulullah Saw.: 


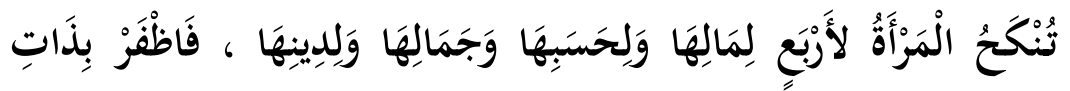 الدِّينِ تَرِبَتْ يَدَاكَ}

Artinya:

"Wanita dinikahi karena empat hal; karena hartanya, keturunannya, kecantikannya, dan agamanya. Maka pilihlah karena agamanya niscaya engkau akan beruntung." (HR. Al Bukhari dan Muslim)

Walaupun pada hakikatnya dalam hadits ini Rasul menempatkan agama sebagai yang terakhir, namun pada kalimat penutupnya Rasul menegaskan yang seakan memberi petunjuk untuk mememilih pasangan dengan melihat agamanya terlebih dahulu, karena dengan demikian akan beruntung; di dunia, lebih-lebih di akhirat kelak.

Dalam kaidah fikih-pun disebutkan bahwa:

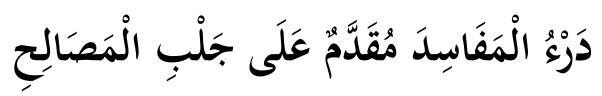

Artinya:

"Mencegah kemafsadatan (kerusakan) lebih didahulukan (diutamakan) dari pada melakukan kemaslahatan."

Pernikahan adalah merupakan salah satu kemaslahatan yang dengannya mendapatkan kebahagaiaan, ketentraman dan keturunan. Namun apabila pernikahan tersebut dilakukan dengan seseorang yang berbeda keyakinan (agama), bukan kebahagaiaan dan ketentraman yang diperoleh, malah sebaliknya. Demikian dengan anak, akan bagaimana anak nantinya, agama dan kepercayaan bagaiamana, maka akan menjadi permasalahan besar dan orang tua khususnya akan dimintai pertanggungjawaban oleh Allah Swt. dikemudian hari. Maka oleh besarnya keburukan yang ditimbulkan, pernikahan beda agama diharamkan oleh Allah dan rasul-Nya. 
Maka dari penjelasan di atas, pernikhan beda agama antara orang Islam (laki-laki dan perempuan) dengan non muslim dalam pandangan Islam dapat dibedakan sebagai berikut: ${ }^{15}$

1. Islam dengan tegas melarang wanita muslim menikah dengan laki-laki non muslim, baik yang musyrik maupun ahli kitab, seperti yang dengan jelas ditegaskan dalam surat al Baqarah ayat 221.

2. Perkawinan laki-laki muslim dengan wanita non muslim dibedakan dalam 2 hal:

a) Perkawinan laki-laki muslim dengan perempuan musyrik tidak dibenarkan atau dilarang dengan tegas sesuai surat al Baqarah ayat 221. Namun, yang menjadi pertanyaan adalah siapakah yang termasuk ke dalam kategori wanita musyrik yang haram dinikahi oleh laki-laki muslim.

b) Tentang pernikahan laki laki Muslim dengan yang non muslim yang ahli kitab adalah hal yang kontroversial dikalangan para fuqaha sejak zaman Sahabat. Menurut Abdul Basiq Jalil dalam tesisnya "Kajian para Ahli Agama, Fuqaha dan Kompilasi Hukum Islam tentang Pernikahan Lintas Agama" tahun 2004 dan juga Ichtiyanto dalam disertasinya tentang Perkawinan Campuran Dalam Negara Republik Indonesia tahun 2003 mengutip pandangan Ibrahim Husen yang merangkum pendapat para fuqaha tentang masalah ini ke dalam tiga golongan yaitu:

1) Golongan pertama, golongan ini termasuk Jumhur Ulama berpendapat bahwa pernikahan laki-laki muslim dengan non muslim Ahlu kitab (pengikut

15 Muhammad Ashsubli. 2015. Undang-Undang Perkawinan Dalam Pluralitas Hukum Agama (Judicial Review Pasal Perkawinan Beda Agama). Jurnal Cita Hukum, FSH UIN Syarif Hidayatullah Jakarta Vol.3 No.2, 2015. Hlm. 295.

Sangaji Jurnal Pemikiran Syariah dan Hukum 
Yahudi dan Nasrani) diperbolehkan, sedang selain Yahudi dan Nasrani, hukumnya haram. Mereka beralasan dengan ayat Alquran surat Al Maidah ayat 5;

"Pada hari ini dihalalkan bagimu yang baik-baik. Makanan (sembelihan) orang-orang yang diberi al Kitab itu halal bagimu, dan makanan kamu halal pula bagi mereka. (dan dihalalkan mengawini) wanita-wanita muhshanat (yang menjaga kehormatannya) diantara wanita-wanita yang beriman, serta wanita-wanita yang menjaga kehormatannya diantara orang-orang yang diberi al Kitab sebelum kamu, bila kamu telah membayar mas kawin mereka dengan maksud menikahinya, tidak dengan maksud berzina dan tidak pula menjadikannya gundik-gundik."

Menurut mereka, dari ayat tersebut dapat ditarik dua argumen. Pertama, ayat ini dengan tegas membolehkan orang muslim memakan makanan orang ahli kitab (kecuali jenis yang diharamkan) dan membolehkan menikahi wanita-wanita Ahli Kitab yang muhsanat. Kedua, dari sisi kronologisnya ayat ini termasuk rangkaian ayat-ayat madaniah, yang turunnya sesudah hijrah, yang berarti ayat yang dapat dijadikan rujukan hukum.

2) Golongan kedua, yaitu golongan yang berpendapat bahwa menikahi wanita non muslim haram hukumnya. Pendapat ini dianut antara lain oleh ibnu Umar dan Syi'ah Imamiah. Mereka beralasan dengan beberapa dalil. Pertama, surat al-Baqarah ayat 221 yang berbunyi:

"Dan janganlah kamu menikahi wanita-wanita musyrik sebelum mereka beriman. Sesungguhnya budak-budak wanita yang beriman lebih baik bagimu daripada wanita musyrik meskipun wanita musyrik itu amat menerik 
hatimu. Dan janganlah pula kalian menikahkan orangorang musyrik dengan wanita beriman, sebelum mereka beriman. Sesungguhnya budak laki-laki beriman lebih baik daripada pria musyrik, walaupun mereka menarik hatimu. Mereka mengajak ke neraka, sedang Allah mengajak ke surga dan ampunan dengan izinnya. Dan Allah menerangkan ayatayatNya (perintah-perintahNya) kepada manusia supaya mereka mengambil pelajaran."

Selanjutnya surat al Mumtahanah ayat 10 yang artinya;

"Hai orang-orang yang beriman, apabila datang berhijrah kepadamu perempuan beriman, maka hendaklah kamu uji (keimanan) mereka. Allah lebih mengetahui tentang keimanan mereka; maka jika kamu telah mengetahui bahwa mereka (benarbenar) beriman maka janganlah kamu kembalikan kepada (suami-suami mereka) orang-orang kafir. Mereka tiada halal bagi orang-orang kafir itu dan orang-orang kafir itu tiada halal bagi mereka. Dan berikanlah kepada suami-suami mereka mahar yang telah mereka bayar. Dan tiada dosa atasmu mengawini mereka apabila kamu bayar kepada mereka maharnya. Dan janganlah kamu berpegang kepada tali (perkawinan) dengan perempuan-perempuan kafir, hendaklah kamu minta kembali mahar yang telah kamu bayar dan hendaklah mereka minta kembali mahar yang mereka bayar. Demikianlah Hukum Allah yang ditetapkan bagi kamu, Allah maha mengetahui lagi maha bijaksana."

Golongan ini menjadikan kedua ayat diatas sebagai landasan dari pendapat yang melarang kaum mukminin menikah dengan perempuan musyrik. Ahli kitab bagi golongan ini termasuk orang musyrik, dengan alasan bahwa orang Yahudi mempertuhan Uzair dan orang-orang Nasrani mempertuhan al 
Masih Isa bin Maryam. Al Quran menyifati mereka sebagai orang yang berbuat syirik, dimana dosa syirik tidak dapat diampuni jika mereka tidak bertobat kepada Allah sebelum meninggal dunia.

\section{F. Faktor Penyebab Nikah Beda Agama}

Sebenarnya banyak sekali faktor-faktor penyebab terjadinya nikah beda agama, khususnya pada masyarakat indonesia. Beberapa diantaranya: ${ }^{16}$

1. Pergaulan hidup sehari-hari dalam kehidupan bermasyarakat. Indonesia memang merupakan masyarakat yang heterogen atau terdiri atas beraneka ragam suku, dan agama. Dalam pergaulan hidup sehari- hari, tidak pernah dibatasi dalam masalah pergaulan. Hal ini sangat berpengaruh pada kehidupan bermasyarakat yang ada di Indonesia yang sudah terlalu erat dalam bergaul tanpa melihat perbedaan agama yang satu dengan yang lainnya sehingga menimbulkan perasaan cinta yang tidak dapat dihindari.

2. Pendidikan tentang agama yang minim. Banyak orang tua yang jarang maupun tidak pernah mengajarkan anakanaknya sedini mungkin tentang agama. Sehingga dalam pertumbuhannya menjadi dewasa, Ia tidak mempersoalkan agama yang diyakininya. Sehingga dalam kehidupannya sehari-hari, tidak mempermasalahkan apabila memiliki

16 Jane Marlen Makalew. 2013. Akibat Hukum Dari Perkawinan Beda Agama Di Indonesia. Lex Privatum, Volume I, Nomor 2 April - Juni 2013. Hlm. 138-139. Lihat juga: Nurhasanah. 2017. Implikasi Larangan Menikah Beda Agama Terhadap Pendidikan Anak Dalam Keluarga. Tidak Dipublikasikan. Fakultas Pendidikan dan Keguruan Universitas Islam Negeri Raden Intan Lampung. 
pasangan yang berbeda agama hingga sampai kejenjang perkawinan atau menikah.

3. Latar Belakang Orang tua. Faktor ini juga sangat penting. Karena pasangan yang menikah beda agama tentu tidak lepas dari adanya latar belakang orang tua. Banyak pasangan yang menikah dengan pasangan yang berbeda agama karena melihat orang tuanya juga adalah pasangan yang berbeda agama. Mungkin bagi mereka tidak menjadi masalah apabila menikah dengan pasangan yang berbeda keyakinan karena berdasarkan riwayat orang tua. Tentu jika kehidupan orang tua tersebut berjalan harmonis, maka akan menjadi contoh bagi anak-anaknya kelak dalam perkawinan berbeda agama.

4. Kebebasan memilih pasangan. Tentu sekarang adalah zaman yang modern, tidak seperti dulu yang dinamakan zaman Siti Nurbaya, yang pada zaman tersebut orang tua masih saja mencarikan jodoh untuk anak-anaknya. Sekarang adalah zaman modern yang dimana para laki-laki dan perempuan dengan bebasnya memilih pasangan sesuai dengan keinginannya. Dengan adanya kebebasan memilih pasangan ini, tidak bisa dipungkiri jika banyak yang memilih pasangan beda agama karena didasari dengan cinta. Jika cinta telah mendasarinya dalam hubungan seorang laki-laki dan seorang perempuan, tidak jarang pertimbangan secara matang dalam suatu hubungan juga termasuk menyangkut agama kurang dapat berperan.

5. Dengan meningkatnya hubungan sosial anak-anak muda Indonesia dengan anak-anak muda dari Manca Negara. Akibat globalisasi dengan berbagai macam bangsa, kebudayaan, agama serta latar belakang yang berbeda hal tersebut sedikit atau banyak ikut menjadi pendorong atau melatar belakangi terjadinya perkawinan beda agama. Dan gengsi untuk mencari pasangan "Bule" juga sangat 
mempengaruhi, sehingga bagi anak-anak muda kawin dengan pasangan luar negeri maupun agama yang berbeda seakantakan sudah tidak menjadi masalah lagi.

\section{G. Dampak Nikah Beda Agama}

\section{Terhadap Kehidupan Keluarga (suami istri)}

Dalam beberapa ayat dan hadits yang telah disebutkan, sebenarnya Allah dan Rasul-Nya telah menyebutkan tentang akibat atau dampak dari melanggar perintah (nikah beda agama). Misalanya dalam surat al Baqarah ayat 221.

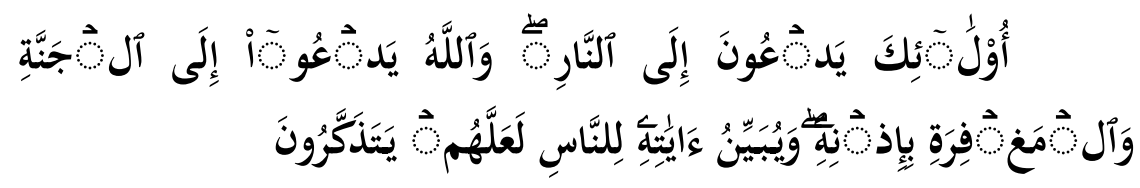

Terjemahnya:

Mereka (pasangan musyrik) mengajak ke neraka, sedang Allah mengajak ke surga dan ampunan dengan izin-Nya. Dan Allah menerangkan ayat-ayat-Nya (perintah-perintah-Nya) kepada manusia supaya mereka mengambil pelajaran." (QS. Al baqarah: 221)

Secara pasti Allah menyebutkan dampak yang terjadi terhadap seorang muslim/muslimah ketika menikah dengan pasangan musyrik, yaitu pasangan tersebut akan menariknya kedalam neraka. Demikian halnya yang disebutkan oleh Rasul dalam haditsnya;
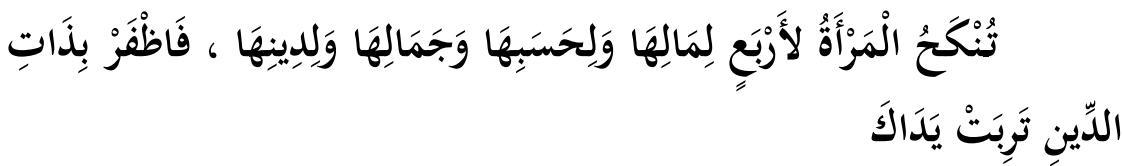

Artinya:

"Wanita dinikahi karena empat hal; karena hartanya, keturunannya, kecantikannya, dan agamanya. Maka pilihlah 
karena agamanya niscaya engkau akan beruntung." (HR. Al Bukhari dan Muslim)

Dalam hadits ini Rasul menjelaskan bahwa bagi sesiapa yang memilih pasangan karena karena mengutamakan agamanya, maka akan beruntung. Beruntung disini bersifat umum, bisa di dunia dan bisa juga di akhirat.

Selain yang disebutkan, dampak lain terhadap suami istri yang biasa ditemukan terhadap nikah beda agama adalah: ${ }^{17}$

a) Perasaan dan suasana yang tidak nyaman hidup bersama dengan orang yang menurut agama/pasangan "salah". Permasalahan tidak nyaman itu diakui atau tidak, lantaran pasangan yang akhirnya menikah itu tetap mempertahankan agama sebagai kepercayaan masing-masing. Hal ini bisa berdampak pada keharmonisan keluarga. Sebab, tujuan menikah salah satunya karena ingin membangun keluarga yang sakinah, mawaddah wa rahmah. Bagi pasangan yang beda agama tersebut, berpotensi hidup bersama tanpa dibarengi dengan kenyamanan. Alasannya karena keduanya masih merasa bahwa agama yang dianut masing-masing sama-sama benar. Sehingga, keduanya tetap mempertahankan agama yang dipercayanya masing-masing.

b) Pasangan nikah beda agama berpotensi memunculkan perasaan khawatir jika anak suatu saat akan mengikuti atau tertarik dengan agama yang dianut pasangan.

17 Hukum Online. 2015. Empat Kelemahan Nikah Beda Agama Dilihat dari perspektif psikologis dan sosiologis. Diakses pada hari Senin 30 November 2015. https://www.hukumonline.com/berita/baca/lt565beb1c50465/ini-empatkelemahan-nikah-beda-agama.

Sangaji Jurnal Pemikiran Syariah dan Hukum 
c) Rasa tidak nyaman secara sosial karena selalu menjadi sasaran pandang masyarakat.

d) Memunculkan perasaan saling curiga. Misalnya, ketika salah satu pasangan melakukan hal-hal yang baik dengan alasan karena dianjurkan oleh ajaran agamanya. Hal itu menimbulkan potensi anggapan yang muncul dari pasangan bahwa ada 'upaya lain' di balik tindakan baik pasangan tersebut.

\section{Terhadap Pendidikan Agama Anak}

Selain berdampak negative terhadap kehidupan keluarga (suami istri), dampak yang paling mengerikan adalah terhadap anak keturunan. Jelasnya anak dari orang tua yang beda agama akan memiliki dua kepribadian atau berkepribadian ganda. Di satu sisi harus pandai menghadapai sang ayah yang beragama Islam misalnya dan disisi lain harus bisa menyesuaikan dengan agama kepercayaan ibunya, kristen misalnya.

Secara umum, pasangan beda agama dibagi menjadi 3 kategori; yaitu pasangan yang sama-sama lemah dalam agamanya, pasangan yang salah satunya kuat dalam beragama sedangkan yang lain lemah dalam agama dan pasangan yang sama-sama kuat dalam beragama.

Dengan berdasar pada pembagian tersebut, maka dampak yang terjadi-pun terhadap pendidikan agama anak setidaknya ada tiga: ${ }^{18}$

a) Pada pasangan yang tidak terlalu kuat dalam beragama atau beragama sekedar formalitas (agama KTP) maka akan berdampak terhadap persepsi anak tentang agama sebagaimana orang tua memahami agama. Secara generatif anak mengikuti keberagamaan orang tua.

${ }^{18}$ Erwin Yudi Prahara. 2016. Pengaruh Pendidikan Agama Pada Anak Dalam Keluarga Beda Agama Di Desa Klepu Sooko Ponorogo. Cendekia Volume 14 Nomor 1, Januari - Juni 2016. Hlm. 31. 
Agama sekedar pakaian atau formalitas. Faktor lingkungan lebih dominan dalam mempengaruhi agama anak, sedangkan orang tua kurang begitu signifikan pengaruhnya.

b) Pada pasangan di mana salah satu pasangan lebih kuat dalam beragama atau lebih aktif dalam mempengaruhi anak untuk masuk dalam agamanya, maka anak akan cenderung mengikuti agama orang tua yang dominan. Dalam keluarga semacam ini, biasanya salah satu pihak aktif berusaha untuk mengenalkan agamanya kepada anaknya, sementara pihak yang lain cenderung membiarkan atau mengalah. Hal ini dilakukan untuk mencegah konflik rumah tangga. Tidak jarang pihak yang mengalah justru mendorong anaknya supaya konsisten dalam beragama. Artinya, anak diminta menjadi penganut agama dengan baik. Tidak jarang sikap mengalah dan sportif pihak orang tua yang mengalah justru mengundang simpati salah satu anak dan karenanya anak berkeinginan untuk mengikuti agama selain yang diajarkan pihak orang tua yang dominan.

c) Pada pasangan yang sama-sama kuat dalam beragama atau sama-sama aktif dalam mengajak anak agar memeluk agama yang dipeluknya memiliki 2 (dua) kemungkinan, yaitu orang tua membuat kesepakatan, atau orang tua tidak membuat kesepakatan. Bagi pasangan yang membuat kesepakatan tertentu, maka komunikasi keluarga dalam hal agama akan lebih terarah sesuai dengan kesepakatan tersebut, baik kesepakatan tentang agama anak untuk mengikuti agama salah satu orang tua atau dibagi secara fair, sebagian ikut agama ayah, sebagian ikut agama ibu. Atau bahkan anak diberi kebebasan dalam menganut agama. Potensi konflik akan 
terjadi pada pasangan yang tidak membuat kesepakatan tertentu karena terjadi kompetesi terselubung dalam mempengaruhi agama anak.

\section{H. Kesimpulan}

Dari penjelasan singkat di atas, penulis menyimpulkan beberapa point penting, diantaranya:

1. Jumhur ulama (mayoritas ulama) sepakat tentang keharaman nikah beda agama ataupun menikah dengan ahli kitab sekalipun, terlebih ahlu kitab pada zaman sekarang tidak seperti ahlu kitab pada zaman Nabi Saw atau bahkan telah hilang.

2. Majelis Ulama Indonesia (MUI) dan Peraturan Pemerintah Rebubrik Indonesia telah sepakat juga tentang haramnya menikah beda agama. Bahkan anak yang lahir dari pasangan beda agama tidak dianggap anak yang sah karena lahir dari pasangan nikah yang tidak sah menurut agama maupun undang-undang.

3. Tidak hanya dalam pandangan agama Islam, larangan menikah dengan pasangan beda agama juga berlaku pada agama-agama atau kepercayaan lain, seperti Kristen Protestan dan Katolik, Hindu dan Budha.

4. Dampak atau akibat yang ditimbulkan oleh pernikahan beda agama sangatlah mengerikan dan berbahasa bagi keluarga dan anak keturunan, maka hendaknya orang tua benar-benar memikirkan matang-matang sebelum melakukan pernikahan atau mencari pasangan hidup. 


\section{Daftar Pustaka}

Hakim, Rahmat. 2000. Hukum Perkawinan Islam. Bandung: CV. Pustaka Setia.

Daradjat, Zakiah. 1995. Ilmu Figh. Yogyakarta: Dana Bhakti Wakaf. Undang-Undang Republik Indonesia Nomor 1 Tahun 1974 Tentang Perkawinan.

Al Zuhaili, Wahbah. 1985. Fiqhu al Islami wa Adillatuhu Juz. VII. Cetakan II. Damaskus: Dar al Fikri.

Ningsih, Ratna Jati. 2012. Perkawinan Beda Agama (Studi Analisis Pemikiran Quraish Shihab dalam Tafsir Al-Misbah). Tidak Diterbitkan. Fakultas Syari'ah dan Ekonomi Islam Institut Agama Islam Negeri (IAIN) Surakarta.

Makalew, Jane Marlen. 2013. Akibat Hukum Dari Perkawinan Beda Agama Di Indonesia. Lex Privatum, Volume I, Nomor 2 April - Juni 2013.

Ihtiyanto. 2003. Perkawinan Campuran dalam Negara RI. Jakarta: Badan Litbang Agama dan Diklat Keagamaan RI Depag.

Abineno. 1982. Manusia; Suami dan Istri. Jakarta: BPK Gunung Mulia.

Fuady, Munir. 2009. Sejarah Hukum. Cetakan I. Bogor: Ghalia Indonesia.

Fatwa Majelis Ulama Indonesia Nomor: 4/Munas Vii/Mui//2005 Tentang Perkawinan Beda Agama.

Undang-Undang Republik Indonesia Nomor 1 Tahun 1974 Tentang Perkawinan Pasal 8 Point F.

Sangaji Jurnal Pemikiran Syariah dan Hukum 
Ruangmom, Redaksi. 2020. Apakah Mungkin Menikah Beda Agama di Indonesia?. diakses $26 \quad$ February 2020. https://www.ruangmom.com/menikah-beda-agama.html Ashsubli, Muhammad. 2015. Undang-Undang Perkawinan Dalam Pluralitas Hukum Agama (Judicial Review Pasal Perkawinan Beda Agama). Jurnal Cita Hukum, FSH UIN Syarif Hidayatullah Jakarta Vol.3 No.2, 2015.

Nurhasanah. 2017. Implikasi Larangan Menikah Beda Agama Terhadap Pendidikan Anak Dalam Keluarga. Tidak Dipublikasikan. Fakultas Pendidikan dan Keguruan Universitas Islam Negeri Raden Intan Lampung.

Online, Hukum. 2015. Empat Kelemahan Nikah Beda Agama Dilihat dari perspektif psikologis dan sosiologis. Diakses pada hari $\begin{array}{llll}\text { Senin } & 30 & \text { November } & \end{array}$ https://www.hukumonline.com/berita/baca/lt565beb1c50 465/ini-empat-kelemahan-nikah-beda-agama

Prahara, Erwin Yudi. 2016. Pengaruh Pendidikan Agama Pada Anak Dalam Keluarga Beda Agama Di Desa Klepu Sooko Ponorogo. Cendekia Volume 14 Nomor 1, Januari - Juni 2016. 